book review

\title{
In Pursuit of the Working Class
}

\author{
Ben Clarke \\ UNIVERSITY of NoRTh CAROLINA, GREENSBORO
}

Owen Jones

Chavs: The Demonization of the Working Class

Verso, London, 2012

ISBN 9781844678648

RRP US\$19.95

Zygmunt Bauman

Collateral Damage: Social Inequalities in a Global Age

Polity, Cambridge, 2011

ISBN: 9780745652955

RRP US\$ 19.95

David Nichols

The Bogan Delusion: Myths, Mischief and Misconceptions

Affirm, Mulgrave, 2011

ISBN: 9780980790443

RRP AU $\$ 22.95$ 
Recent decades have seen renewed prejudice against those living in poverty. The disparaging terms used to describe the working classes are not the inevitable result of the exploitation that has, in many places, shifted from coal mines to coffee shops, but the product of relatively autonomous cultural narratives. These shape as well as interpret material conditions; images of violent, intoxicated young men in hooded tops loitering in groups at street corners and irresponsible single mothers in tracksuits watching soap operas all day in council flats provide a simple, fictive explanation for inequality that enables its extension. In ostensibly democratic advanced capitalist societies the exclusion of a substantial proportion of the population from economic and political power depends on the ability of dominant groups to determine how the less fortunate are perceived and to limit empathy with them. In particular it depends on the idea that there is, in Margaret Thatcher's famous phrase, 'no such thing as society' (quoted in Jones, 47), that individuals are wholly responsible for their own situation. This demands a suppression of the concept of class with its emphasis on shared economic interests and cultural traditions. Despite their differences, Chavs, The Bogan Delusion and Collateral Damage all analyse the complexities elided by the myth of the autonomous individual, demanding a renewed attention to economic injustice and the prejudices on which it depends. Taken together, they suggest, as Jones puts it, that 'class is back with a vengeance', (vii) even if the category must be the object as well as the means of critical analysis.

The marginalisation of the concept of class means, in practice, the rejection of the term 'working class'. This is a critical rather than descriptive category, and its deliberate erosion has significant political consequences. It does not simply name a position in a social hierarchy but insists that such structures are founded, in the last instance, on relations of production. To be working class is to be defined by the lack of any resource save one's own labour. The term has not only been essential to leftwing organisations but helped for a long time to sustain what Ross McKibbin called a 'kind of folk-Marxism, quite independent of actual party-political allegiances'1 amongst the working class themselves, who recognised that they created wealth they did not share. It provided a basis for individual and collective identities, enabling people to take pride in their contribution to the common good and show 
solidarity with others who shared their experience of exploitation. To describe oneself as working class was to insist on one's foundational importance to society.

The displacement of the term marks a political as well as material change from ideas of common emancipation to an individualism that constructs poverty as a sign of personal failure. This process has a long history in the United States where most of the population identify themselves as middle class regardless of their income or occupation. Noam Chomsky, discussing his daughter's teaching in a community college, observed that her 'working-class students ... do not consider themselves working class', which is a 'sign of real indoctrination'.2 The last presidential election was fought partly over control of the term 'middle class', a category which now signifies little but a desire for inclusion in political and economic life. The marginalisation of the idea of the working class is not confined to America, though. In Britain, it has come under sustained pressure from both Labour and Conservative governments; even when the concept of class is not rejected outright, the working class is frequently represented as a historical residue, an ageing group of white, male industrial workers whose supposed failure to adapt to new conditions demonstrates their economic and political obsolescence. Contemporary society is increasingly conceived as divided between a broad, vaguely defined middle class and a threatening underclass responsible for its own condition. The terms used to describe the latter, such as 'chav', are inherently pejorative and do not provide a foundation for individual identities or collective action. The change in the representation of the poor, even to themselves, is part of a significant shift in power. Consequently, there is 'something at stake' in its analysis, to use Hall's famous phrase. $^{3}$

This is precisely the kind of area in which one might reasonably expect cultural studies to be most engaged. The concept of class was initially central to the field. Foundational figures such as Richard Hoggart and Raymond Williams drew on their own childhoods to explore the experience of people who had been excluded from public and academic discourse, and a considerable amount of early work focused on the ways in which social categories were reinterpreted after World War II in the context of increasing working-class prosperity. Class has not been central to cultural studies for the past few decades. As Sue Owen argues, 'other categories such as race, gender and sexual orientation have been prioritized'," a process Sally Munt traces 
back to the 1970s, 'when the CCCS [Birmingham Centre for Contemporary Cultural Studies] moved away from working-class (primarily youth) subjects and subcultures, to critique other social structures' ${ }^{5}$ This shift was at once a necessary challenge to the limitations of established left-wing thought and a pragmatic response to a series of defeats for the labour movement; as Jones argues, 'history actually seemed to be on the side of those fighting for the emancipation of women, gays and ethnic minorities'. (255) This turning away from class as a critical category was informed by an engagement with Continental European philosophy that exposed the conceptual and methodological limitations of earlier radical scholarship, though this theoretical work often became an end in itself, detached from a broader political practice. The most conspicuous example of this was perhaps postmodernism; as Terry Eagleton argues, what began as 'a way of valuably reaching beyond certain classical political questions, such as why most people do not get enough to eat ... ended up by all but edging them from the agenda'. 6 The engagement with problems of identity and representation often displaced rather than extended a concern with material divisions.

In insisting on the need for a return to class it is, as Munt argues, important to avoid the 'fragmentation of sympathetic discourses'.7 Chavs, The Bogan Delusion and Collateral Damage all recognise the complex interactions between distinct structures of power. The new concern with class involves an attempt to rethink the concept within analyses of gender, race and sexual orientation, rather than a return to earlier methodologies from which these categories were often absent. The notion that a concern with poverty involves privileging the interests of white men reproduces a conservative myth of a narrowly defined, static working class, whose interests are set against those of women and ethnic minorities. In practice, as Jones argues, the working class is 'far more ethnically mixed than the rest of the population', (243) and is now better represented by a 'low-paid, part-time, female shelf-stacker' than a 'blue-uniformed male factory worker'. (167) The return to class does not mean ignoring other forms of oppression, but rather analysing the shared economic interests of what is otherwise the most diverse section of society.

Owen Jones' Chavs deserves but does not need further praise. It has already achieved considerable success and the new edition of the text, which includes a valuable new preface on the 2011 riots in Britain, is preceded by enthusiastic 
reviews by figures from John Cruddas to Eric Hobsbawm. As perhaps the most influential recent contribution to debates about class, it is significant that it was not written by an academic. Jones has worked for the trade unions and as a parliamentary researcher, and his background in the labour movement shapes the text, which concludes by arguing for a 'new class politics'. (268) It also informs his prose, which addresses a general rather than a specialist audience. Despite an occasional weakness for dramatic adjectives, his writing is direct and communicates a real anger. Chavs is polemical in the best sense, seeking to change conditions rather than just describe them. It does not depend simply on a sense of outrage but is founded upon a considerable body of research. Some of the most memorable passages describe personal interviews with politicians and their advisors, as when Thatcher's first chancellor, Geoffrey Howe, flounders after Jones reads him 'statistics showing that the living standards of the poor had actually declined' (63) under successive Conservative governments, or when Matthew Taylor, Tony Blair's former head of strategy, describes 'a particular strand of uber-Blairism' as 'just fucking mad'. (101) In the main, though, Jones' arguments are grounded in statistical data and the close reading of particular texts and images. Chavs is an accessible but serious contribution to debates about poverty. Its success demonstrates the continued existence of the, supposedly mythical, intelligent general reader and the possibility of an informed discussion about the subjects it addresses that extends beyond universities, think tanks, and political parties.

Jones focuses on the question of how 'hatred of working-class people [has] become so socially acceptable' (2) that it can be openly expressed even at a time when other forms of prejudice are publicly disclaimed. As its title suggests, the text focuses on the term 'chav', which in Britain has come to encompass 'any negative trait associated with working-class people-violence, laziness, teenage pregnancies, racism, drunkenness and the rest'. (8) The word is effective partly because it is slippery, describing in some contexts a dysfunctional minority and in others anyone poor, an ambiguity that means that it is used to reinforce distinctions of status within working-class communities as well as to discriminate against them. As Jones recognises, the claims that 'working-class people are not demonised' because "chav" is simply used to designate anti-social hooligans and thugs' are disingenuous since those 'on the receiving end' of the word 'are exclusively working class'. (7) Its 
fluidity serves a coercive function, forcing the poor to try to distance themselves from a 'demonised grouping' (xii) to which they can always be returned by those with more material and social power. In this respect, it functions in the same way as word such as 'slut', which at once polices the behavior of individuals and expresses a view of all women. As Jones observes 'class hatred and misogyny often overlap', (xiv) and some of the most violent attacks on the poor have been directed at young women, particularly single mothers. These attacks are often highly sexualised using prurient accusations of promiscuity to suggest a broader moral failure that justifies their treatment. The Times journalist James Delingpole's images of 'gym-slip mums who choose to get pregnant as a career option' and 'pasty-faced, lard-gutted slappers who'll drop their knickers in the blink of an eye' (quoted 128) are particularly distasteful examples of a widespread contempt for working-class women.

Chavs is sensitive to the rhetorical strategies used to legitimise class prejudice and the text contains some perceptive close-readings of recent images of the poor. These vary from brief comments on representation of the 'quasi-bestial lower orders' (131) in James Watkins' film Eden Lake and the character of Vicky Pollard from the television sketch comedy Little Britain, to a more sustained analysis of the 'hounding of Jade Goody'. (123) The best and longest of these close-readings considers the different responses to the disappearance of two children, Madelaine McCann and Shannon Matthews. In the two weeks after McCann's disappearance from an 'upmarket holiday resort in the Portuguese Algarve' (13) in 2007, a public appeal raised more than $£ 2.6$ million in reward money for her return. After Matthews disappeared from an 'impoverished estate' (16) in Dewsbury in the north of England a year later, a similar appeal raised ' $£ 25,500$ (although this later rose to $£ 50,000)$... nearly all of which had been put up by the Sun'. (14) When it turned out that Matthews' abduction had been staged by her mother, who hoped to 'pocket the reward money', (19) the News of the World commentator Carole Malone represented the crime as characteristic of a whole 'sub (human) class' of 'good-for-nothing scroungers who have no morals, no compassion, no sense of responsibility and who are incapable of feeling love or guilt'. (quoted 22) Privileged journalists and politicians used the example of a 'chronically dysfunctional individual' (26) to condemn 'anyone from a similar background'. (31) The cases raise a series of 
questions about the way prejudice functions politically and the widening divisions between the poor and the people who represent them (in both senses of the word).

Throughout Chavs Jones analyses the relation of class prejudice to the neoliberal economic ideas that dominated government policy in Britain from the late 1970s. As he argues, 'the working class as a concept [was] the mortal enemy of Thatcher's everyone-for-themselves model of capitalism' (47) and successive Conservative governments systematically destroyed working-class institutions and communities, a process that continued under New Labour. These attacks were accompanied by the denigration of working-class people in popular culture and, in the past two decades in particular, class prejudice has become widespread even among the supposedly progressive middle classes. This process has been partly enabled by the appropriation of the language of identity politics, which is used to construct the working-class as an ethnic rather than economic category as in accounts of the 'white working class' that represent them as the racist and misogynist residue of a lost industrial past, unable to adapt to a supposedly classless multicultural society. As Jones argues, the 'new liberal bigotry' is founded on the belief it is ' $\mathrm{OK}$ to hate the white working class' because they are 'themselves a bunch of racist bigots'. (9)

This process is not confined to Britain. David Nichols identifies a similar strategy in representations of 'bogans' in Australia, who are also condemned for their supposedly 'inherent racism'. (149) The bogan is a distinctively Australian concept, as Nichols' demonstrates, shaped in part by tensions between cities and suburbs, and associated with plasma screen televisions and McMansions (52) rather than inner-city tower blocks and knife crime. There are parallels with the 'British phenomenon of the chav and chavette' (60) and the 'American idea of "white trash"'. (56) In each case stereotypes at once express and disavow 'class hatred', (72) constructing an image of a group whose marginalisation is justified by their own prejudices and fecklessness. In Australia, as in Britain, this hatred is not confined to the right. The image of the bogan as a racist 'conservative' who thinks 'the environment generally and global warming are bullshit' (52) is also used to legitimise the hostility of what Nichols' describes as an 'antibogan "elite"', (214) whose declared liberalism is expressed primarily through lifestyle and consumer choices. 
The Bogan Delusion is in many senses a less substantial book than Chavs. Comparatively brief, it is loosely structured and, while this is part of its deliberate informality, it also means that it sometimes moves too rapidly from point to point without fully developing its readings. The abrupt conclusion to the discussion of the way in which the death of Jaidyn Leskie in 1997 was used to demonise the 'lifestyles and personalities of the adults supposed to take care of him' (95) and the town he inhabited, is only one, relatively minor example of this. Nichols might also have made more of his own experience of living in Broadmeadows, a northern Melbourne suburb. His personal investment in the subjects he discusses is prominent in the opening chapter but recedes as the text continues. Though he does not fully explore the critical possibilities of the autobiographical form, on the whole The Bogan Delusion is a useful, provocative discussion of the myths which have filled the 'space left behind by the working class'. (10) As Nichols argues, the term 'bogan' has 'so many definitions it's meaningless' (31) but it consistently serves as a 'code word for the "other" ... a way to use humour or "common sense" or both to relegate any problematic person, place or political position to the scrap heap'. (214) In a familiar rhetorical move, it represents social hierarchies as founded on distinctions of behaviour and taste rather than economic divisions; bogans are supposedly defined by their tight jeans and mullets, their love of Cold Chisel and the Angels, rather than income. The term rejects structural analyses of society, which might provide a basis for its transformation, insisting that bogans are responsible for attitudes towards them.

Nichols is a perceptive, often entertaining writer alert to the evasions and contradictions of the prejudices he describes. This includes the question of whether bogans are defined by their cultural preferences, which could be altered, or their inherent qualities: 'Can you slip between begin a bogan and "normal" or "hipster" and "non-bogan" as easily as changing out of your trackie daks into something power-dressy, or are you born into boganness, confirmed the minute you get your first rat's tail, condemned to stare out at the civilized world like the Neanderthals who lived alongside Homo Sapiens, but were never invited to their parties?' (212) As this passage demonstrates, his prose is conversational and engaging. Nichols lectures on urban planning and, although his book avoids specialist terms and references, his expertise is apparent in his discussion of the myths that shape 
attitudes towards the suburbs. Dedicated to the 'people of Broadmeadows', he includes them in its potential audience, rather than seeing them simply as objects of analysis. The Bogan Delusion is an intelligent, readable contribution to debates on 'class hatred' (72) in contemporary Australia, posing valuable questions even where it does not allow itself sufficient space to address them.

Predictably, Zygmunt Bauman's Collateral Damage is a more overtly scholarly work. A wide-ranging text, it includes a detailed critical analysis of Carl Schmitt's ideas and a chapter on the 'natural history of evil', (128-49) as well as sections more explicitly focused on class. It is consistently concerned with questions of political and economic inequality. Bauman repeatedly emphasises the widening gaps between rich and poor, powerful and powerless, and the consequent breakdown of social cohesion and the sense of mutual responsibility. This is demonstrated by the concept of the 'underclass', a term which suggests a group that falls 'outside any meaningful, that is function and position orientated, classification' and consequently lacks 'the rights owed to recognized and acknowledged members of society'. (3) The treatment of the people the term 'underclass' defines is determined by instrumental rather than ethical criteria, consistent with a 'tendency to reclassify poverty ... as a problem of law and order'. (4) Increasingly the perceived function of government is not to ameliorate the condition of the poor, let alone transform the economic system responsible for their condition, but to prevent them from troubling the more prosperous. One result of this is the kind of social fragmentation and isolation embodied in phenomena such as gated communities which, despite their name, demonstrate people's desire 'to be left alone'. (66) What Bauman calls 'mixophobia', the fear of 'confronting strangers face-to-face' (64) is, like high 'incidence of mental illness ... prison populations ... obesity, teenage pregnancies ... and death rates for all social classes', (38) the cost of inequality. In making this argument Bauman, like Jones, draws on Wilkinson and Pickett's The Spirit Level, a book that has been instrumental in returning questions of social justice to the centre of cultural criticism.

Bauman argues that current inequality depends upon a process of “individualisation” by decree'. People are increasingly 'expected to devise individual solutions to socially generated problems' and, as a consequence, the 'polarisation of prospects and chances' becomes a 'self-propelling and self-accelerating process'. 
(17) This process is further advanced in Britain and the United States than it is in the Nordic countries but it cannot be addressed simply at the level of the nation. Government policy is important but the problem is capitalism. As Bauman observes, impoverished young people in Bradford, a northern English city close to where he lives, are 'collateral casualt[ies] of profit-drive, uncoordinated and uncontrolled globalization' (4) rather than purely local circumstances. He contends that early twentieth-century radical movements centred on 'revolutionary specialists' (34) do not provide a model for a new oppositional politics and argues for developing open, democratic structures that would enable 'the two-way translation between the language of individual/familial interests and the language of public interests'. (11) Politics can no longer be contained by the boundaries of the state as '[p]ower is already global'. The failure to recognise this has reduced nations to 'local "law and order" police precincts, as well as local dustbins and garbage removal and recycling plans for the globally produced risks and problems'. (23) The urgent task now, Bauman argues, is to 'raise human integration to the level of humanity' and develop a politics adequate to this expanded understanding of community, a process he sees as 'literally, a matter of (shared) life or (joint) death'. (25)

Since the economic crash of 2008, economic divisions have increased significantly and government provision for the vulnerable has been cut as administrations have used the rhetoric of austerity to extend neoliberal policies. Resistance to this cannot, obviously, be a primarily academic matter, but scholars can make an important, even essential, contribution to a broad political struggle. The response to the financial crisis has too often been constrained by a failure to conceptualise inequality in a way that would enable a challenge to its structural foundations or provide a basis for effective collective action. A broader, more inclusive concept of class, which built on the achievements of feminist and postcolonial practice, could provide a foundation for solidarities based on the recognition of shared material interests and a common experience of cultural exclusion. This requires a challenge to a deliberately fostered individualism that insists that poverty is always a consequence of personal failure and that the marginalised and vulnerable have no claim on the sympathy and resources of the more prosperous. The success of Chavs demonstrates the potential audience for such work. At the moment much of this is being produced outside universities but, 
as Collateral Damage suggests, there is also an important role for rigorous theoretical, empirical and interpretative scholarship. We cannot accept the dismissal of the working class as 'chavs', 'bogans', or 'white trash', and those in cultural studies, with its historical commitment to social justice, have a particular obligation to intervene in the attempts to shape a new class politics.

Ben Clarke is assistant professor of English at the University of North Carolina at Greensboro. He has published on subjects including George Orwell, public houses, Englishness, and the politics of prose style. His first monograph, Orwell in Context, appeared in 2007, and he is co-author, with Michael Bailey and John K. Walton, of Understanding Richard Hoggart (2011).

\section{-NOTES}

${ }^{1}$ Ross McKibbin, Classes and Cultures: England 1918-1951, 1998; repr. Oxford University Press, Oxford, 2000, p. 139.

2 Noam Chomsky and Donaldo Macedo, 'Beyond a Domesticating Education: A Dialogue', in Chomsky on MisEducation, eds Donaldo Macedo, Rowman and Littlefield, Lanham, 2000, pp. 15-36, p. 35.

3 Stuart Hall, 'Cultural Studies and its Theoretical Legacies', in Cultural Studies, eds Lawrence Grossberg, Cary Nelson, Paula A. Treichler, Routledge, London and New York, 1992, pp. 277-86, p. 278.

${ }^{4}$ Sue Owen, 'Hoggart and Women', in Richard Hoggart and Cultural Studies, ed. Sue Owen, Palgrave, Houndmills, 2008, pp. 227-42, p. 227.

5 Sally R. Munt, 'Introduction', in Cultural Studies and the Working Class: Subject to Change, Sally R. Munt, Cassell, London, 2000, pp. 1-16, p. 5

${ }^{6}$ Terry Eagleton, The Illusions of Postmodernism, Blackwell, Oxford, 1996, pp. 24-5.

7 Munt, p. 7. 